\title{
Constructing productive post-school transitions: An analysis of Australian schooling policies
}

\author{
Stephen Billett, Sue Thomas, Cheryl Sim, Greer Johnson, Steve Hay, Jill Ryan \\ Faculty of Education, Griffith University, 4152, Australia
}

\begin{abstract}
Not having clear pathways, or the social means and personal capacities to make a productive transition from schooling can inhibit young people's participation in social and economic life thereafter. This paper advances an analysis of how policy documents associated with senior schooling from across Australian states address the needs of students who are most at risk of not securing productive transitions. The review identifies that many of the goals emphasised the autonomy of students in taking control of their own transitions. However, such individualistic views downplay the importance of the mediating role that access to cultural, social and economic capital is likely to play in the negotiations involved in making a productive transition. Thus, the needs of 'at-risk' students who may have limited access to the forms of capital offering the best support for these negotiations are not well acknowledged in the policies.
\end{abstract}

Keywords: youth transitions, post-school pathways, education policy

\section{Introduction}

In advanced industrial economies, such as Australia, social and economic changes have dramatically altered young peoples' experiences of the transition from secondary schooling to post-school life. Such transitions now involve the negotiation of diverse, complex pathways (te Reile 2004; OECD 2009) to various destinations including employment, further education, or even disengagement from both work and education (McMillan and Marks 2003). Well-organised pathways that connect initial education with work and further study have been identified as one of the key ingredients of successful transition systems (Raffe 2008). For most young people, ease in negotiating these pathways is premised on their high school performance and the clarity and achievability of post-school goals they (or their families) have established (Ball 2003). For young people aiming towards further education, depending on their particular schooling context or performance at school, the pathways on offer can lead either to participation in their preferred choices of university or tertiary education courses, or frustration in not being able to access their preferred option. For other young people opting to enter the workforce directly after leaving school, pathways might lead to further training such as apprenticeships or directly to paid employment requiring no further education.

However, pathways leading directly to employment are becoming more perilous as the educational requirements for entry into well-paid and esteemed employment increases. Hence, for school leavers without high levels of school achievement, or for those who leave early and/or without clear goals, pathways may be more restricted and the consequences potentially more uncertain and limiting. It follows that an important educational goal is to assist such students secure productive post-school transitions through processes that will initially enable them to identify post-school destinations they can aspire to and are suited to their interests and capacities, and then receive appropriate guidance to reach those destinations. Indeed, the OECD (2009) notes the importance of designing and developing transitions in a 
lifelong learning perspective, with effective connections to post-school destinations. Importantly, the experiences of schooling that lead to post-school transitions need to be invitational for all students, regardless of capacities and social origins and access to particular kinds of cultural, economic and social capital.

With these concerns positioned centrally, this paper advances an analysis of eight schooling systems' policy documents on post-school transitions. Many of the goals for schooling emphasised the autonomy of students in taking control of their own transitions. Yet, the requirement to exercise such agency is likely to be unevenly required by school students. Indeed, the very students who lack access to appropriate cultural capital (e.g. young people at risk) are likely to be required to exercise the most personal agency in negotiating effective transitions, yet may well be the least equipped to do so. So, such an emphasis on student agency downplays the importance of the mediating role that access to cultural, social and economic capital likely plays in the negotiations involved in making a productive transition from schooling. Hence, it was concluded that the needs of 'at-risk' students who may have limited access to the forms of capital offering the best support for these negotiations are not well addressed in these policies.

In advancing this case, the paper proceeds as follows. Firstly, the importance of schooling experiences for providing productive transitions to post-school work or study are discussed setting out the premises for the policy analysis to follow. An explanation of procedures used to analyse the eight (six state and two territory) policy documents is then provided. The analysis proceeds by identifying key themes and emphases underpinning the stated purposes of senior schooling through a consideration of their goals and intended means by which productive transitions are to be achieved. From this analysis of these documents, particular constructions of productive transitions across the policy documents are captured and discussed in terms of how they address the needs of students who are most at risk of not securing such transitions. The next section backgrounds the analysis, discussing productive transitions as an educational concern.

\section{The importance of productive transition to post-school work or study}

It is necessary to neither over-emphasise nor understate the importance of productive transitions from school to work. The demographic trends in many advanced industrial economies, including Australia, suggest that over the next few decades, young workforce entrants will become scarcer. Consequently, they may well be in a strong position to negotiate their preferred employment options and worthwhile work. There is also clear evidence that many individuals move to their preferred form of study or employment, but later elect to pursue entirely new programmes of study or occupational trajectories (e.g., Hodges 1998). All of this suggests that an initial indeterminate or unfruitful (i.e., non-productive) transition from school life is not necessarily a personal catastrophe, particularly for those who have the capacities, cultural capital, resources, and opportunities to negotiate and secure worthwhile work and/or further education.

Nevertheless, school-to-employment transition is a life phase that presents significant risks for some groups of school leavers, whilst reinforcing opportunities for others. Researchers and policy makers in many countries (see, McMillan and Marks 2003; Department for Children Schools and Families 2007) have consistently found that school leavers with limited success at school or low levels of literacy and numeracy can be structurally disadvantaged and, potentially, face a lifetime of struggle to secure worthwhile, on-going and well-paid employment. For instance, 
Vanoverberghe et al. (2008) found that the level of education attained by young people had the most pronounced effect on the length of the period of joblessness experienced upon leaving school.

There are also risks for young people associated with becoming dependent upon others and being excluded from meaningful participation in civil society (Quicke 1999). Noteworthy here is that individuals' sense of vocation is often central to how they see themselves and their sense of belonging within a community (Billett 2006). Indeed, a key transition from childhood to adulthood is claimed to be that resulting in an occupational identity that suits an individual's identity or sense of self (Erikson 1968). Yet individuals need the necessary social capital to be able to shift and adjust that identity according to social and economic circumstances. These issues reinforce the salience of transitions that assist individuals to identify occupations for which they are best suited and most interested in, and the need to organise pathways for realising them.

Issues about participation in work life and the opportunities to secure worthwhile work that go beyond considerations of self are also important. The availability of employment that traditionally provided entry points into the labour market for young people is changing (Ball, Macrae, and Maguire 1999). For example, in developed economies such as the UK and Australia, there has been significant employment growth in contingent service work that is often relatively low paid, insecure and particularly prone to fluctuations in demand. Indeed, Simmons (2008) claims the UK economy is increasingly based on low-skill and low-waged work, contrary to policy claims that the need for competitiveness in the global economy is increasing the demand for high level knowledge and skills. So, there are only so many worthwhile jobs on offer, yet much competition for them. Certainly, there is growth in professional and para-professional forms of work. It is in these areas that the most likely growth in well-remunerated employment resides. Yet, securing such employment usually requires high levels of education and, invariably, participation in tertiary education and a preparedness to engage in lifelong learning. Consequently, for young people without institutionalised capital in the form of specialised qualifications achieved through post-compulsory education, these kinds of employment remain unobtainable.

Securing productive post-school transitions has always been an important component of many nations' educational project. This is never more so in times of economic crisis which may involve high levels of youth unemployment and intense competition for desirable work. Therefore, it is not surprising that governments worldwide continue to give considerable attention to understanding these transitions and how students are able to negotiate them effectively. Moreover, the aims to which transitions are directed reflect cultural attitudes towards young people that dominate in particular periods. For example, in the United States in the 1920s young peoplespecifically young unemployed men-were seen to be a problem to be managed through a productive transition to work. The solution in this case involved identifying educational purposes and curriculum means to address this problem. In all, it favoured a more general and educational institution-based provision of vocational education (Gonon 2009). The perceived failure of schooling and inadequacies of American workplaces led to an institutionally-based vocational education provision that incorporated a strong emphasis on education for general educational outcomes. The case was similar in Australia where, up until the late 1980s, the institutionally-based education provided for apprentices extended to liberal, general and physical education. In part, this provision was to develop further the capacities deemed 
essential for vocational education students' participation in society, and to redress a perceived failure on the part of schooling in developing such capacities.

Recently there has been a shift to an alternative view of transition. This alternative view moves from an understanding of young people as a problem to conceptualising them as a resource whose potential needs to be nurtured for both social and economic purposes (Walther, du Bois-Reymond and Biggart 2006). Walther and colleagues argue that European policy imperatives are now driven by a need to engage young people in securing employment and careers and to shift their role from being recipients of welfare to co-producers of welfare for others. It is noteworthy that the shift in focus is occurring in an era of late modernity where the future is held to be increasingly uncertain and filled with risk (Bauman 2002), and life trajectories are both diversified and becoming more individualised (Beck and BeckGernsheim 2002). Individualisation refers to the processes and imperatives driving individuals' decision-making as they engage in constructing their life experiences, rather than these being a given as might be the case in more predictable circumstances (Ray 2005). Beck and Beck-Gernsheim (see, Beck 1992; Beck and Beck-Gernsheim 2002) propose individualisation as both a product and component of the erosion of industrial society, including the breaking down of class structure, gender relations and the role of family.

However, addressing the apparent inevitability of individualisation evident in accounts of late modernity, some researchers have pointed to the crucial role played by governing authorities and policy makers themselves as mediators of this phenomenon (Dean 1999b; O'Malley 2004). Over the past 30 years, neoliberal policies have sought to reconfigure welfare by recasting social and economic risks as the responsibility of individuals who are required to manage them principally though the mechanism of markets (see, Dean 1999a). Neoliberalism is characterised by a withdrawal of the state from the provision of welfare and social services. Under this policy orientation, the role of the provider state is displaced by transferring responsibility for the activities of government to devolved elements such as regions, communities and, perhaps most centrally, to individuals (Peters 2005). In this context, governments have sought to constitute particular kinds of citizens who hold themselves responsible for their own self-government (Rose 1996). This approach to governance responsibilities emphasises individualisation often by exhorting people to calculate and manage their own risks, and, accordingly, make strategic investments in themselves at critical points during their lives (Peters 2005). In short, it invests greater expectations in them being able to exercise their own personal agency and self governance. Such approaches assume that troublesome transitions are an outcome of personal dispositions and 'employability' (Simmons 2009).

In education, policy prescriptions have promoted lifelong learning as a means by which individuals are urged to insure themselves against the risk of unemployment and social exclusion. Thus, broad engagement with individualisation is seen not so much as an inevitable consequence of late modernity, but rather as a strategic incorporation in various forms - the entrepreneurial self, the creative self (Hay and Kapitzke 2009b) - across multiple neoliberal programs of government (O'Malley 2004). Therefore, whereas "youth as a problem implied a corrective and treatment intervention, a reconceptualisation of youth as a resource calls for policies that aim to mobilise and activate young people" (Walther, du Bois-Reymond and Biggart 2006, 11). These claims are aligned with other similar studies across European countries (Evans 2002) and in Australia (Stokes and Wyn 2007), in promoting the need for young people to engage actively in and manage their own learning. Stokes and Wyn 
(2007) note the formation of personal-occupational identities as a central outcome of the negotiations that constitute these transitions, echoing other public policy agendas, such as the need for workers to manage their lifelong learning for work, and government policies directed at mobilising and assisting, rather than providing, that learning (Edwards 2002; Field 2000).

However, while social change and transformations in orientation of approaches to governance have worked together to increase expectations of individualisation, such as in school-to-employment transitions, the risks associated with this are, in fact, borne disproportionately by some groups of young people. This is because not all young people are as able to negotiate productive transitions as others, with social origins playing an important role (cf., Breen and Jonsson 2005). Bourdieu and Passeron (1977) emphasise the potency of families' social, economic and cultural capital, in shaping both students' educational choices and decisionmaking processes. These authors elaborate cultural capital in terms of institutionalised capital, such as the families' qualifications; embodied capital, such as the families' values, beliefs and dispositions, and objectified capital such as books and other artefacts that grant access to the cultural capital required for effective decisionmaking about schooling.

Indeed, Bourdieu and Passeron (1977) claim that students' success at school is more likely when there is a direct 'fit' or congruence between a student's cultural capital and the requirements of schooling. However, the concept of capital does not imply simple determinism because individual actors can adopt strategies for innovation and change that transcend such structural contributions (Bourdieu 1990). For example, recent work in Australia has shown that low socioeconomic status need not necessarily be determinate of a poor transition (Bedson and Perkins, 2006). Therefore, as Evans (2002) notes, although families' economic and social capital is undoubtably important for securing preferred and privileged education and employment options, it is not determinant, and can be mediated. Yet, without such mediation, and as demonstrated over time and in different ways in Australia, factors such as families' economic, social and cultural capital mediates the capacities students bring to their engagement in and decision-making about education that does much to shape their options and successes (Connell 2003).

That is, students' choices about transitions from education to employment evolve through time-dependant interactions of individual decisions and pathways in the context of institutions and changing opportunities (Heinz 2009). The interplay among individual efforts, group-based strategies and macro social structures is dynamic and has been described by Shanahan and Hook (2000) as 'bounded agency'. Not only is students' agency constrained and shaped by macro social frames but students with the economic, cultural and social capital that does not fit that of the school are more likely to experience a differentiated curriculum, with less emphasis on skills of self-directed and independent learning (Anyon 2005). These explanations concur with Australian studies that found self-directed learning initiatives are best suited to students who have developed the capacities to be self-organised and directed in their studies (i.e., students who are high performing), and that many other schoolage students flounder in such arrangements (Billett et al. 1999; Pollock, Chandler and Sweller 2002).

Nevertheless, regardless of whether young people are viewed as a problem to be solved or as a resource to be exploited, educational responses need to be clear on two matters: what leads to productive transitions for the diverse range of students in compulsory education and what means should be offered to meet their diverse ways 
of engaging in and securing effective transitions. The responses likely need to include recognition of some students' limited access to the kinds of cultural, economic and social capital that support transitions. Thus, students may need assistance to prepare for their engagement in productive negotiations, albeit in diverse ways, in what are held to be more demanding, uncertain and risk-oriented times. It follows, that if students are expected to take key roles in these negotiations, in cases where social disadvantage limits their capacities to engage in productive ways, then schooling needs to be directed towards ameliorating the effects of disadvantage as far as possible. Thus, the extent to which education policies account for the socio-economic context of young people transitioning from school to employment provides a platform for appraising the educational purposes, goals and means articulated in the policies.

\section{Approach to analysis of policy documents}

Education policy documents are important for understanding transitions because, as Taylor et al. (1997) note, public policy is more than a specific document or text. Rather, as te Reile $(2004,247)$ argues, "the way that policy conceptualises transition affects the structures and practices available to young people (e.g., through imposed reforms and funding), thus enabling some forms of transition and hindering others." As such, the policies of Australian state and territory departments that administer public schooling are central to what is enacted in the nation's schooling systems, and are worthy of constructive and critical analysis.

Consequently, to capture how productive transitions for school students might be intended to be realised, particularly for those students categorised as 'at-risk', policies that shape what schooling is deliberately seeking to achieve must be considered. Eight policy documents produced by the six Australian states and two territories were reviewed. These documents were selected as, under Australia's federal arrangements, the states and territories retain constitutional responsibility for schooling, schooling policy and the administration of school systems. However, their policies and practices are shaped also by federal government priorities, in particular, through tied funding. The documents selected for analysis fall into three distinct categories as illustrated in Table 1.

(Insert Table 1 about here)

The left hand column lists three reports of reviews of education that contained recommendations for policy and practice. The middle column lists those that comprise implementation plans or strategic plans which detail strategies and/or initiatives. The right hand column lists those documents that are ministerial policy statement on Vocational Education and Training for school students in Western Australia (Western Australian Government 2005).

While educational policy documents cannot account for or explain what actually occurs in schools, they can offer insights into what Miller and Rose (2008) have termed governing rationalities, that is, the ways that authorities seek to define the objects of government, including who and what should be governed, and the problems and goals to which government should be directed. Despite any gaps between what is intended and enacted, let alone what is experienced by students, policy documents articulate the purposes, goals and means that are central to schooling as an intentional educational enterprise. Thus, the documents were analysed with a view to investigating how the transition through senior secondary schooling to life after school was regulated by and through texts (Freebody 2003). Such an analysis 
is based on a critical theory perspective of textual analysis that seeks to not only decode meaning from the words used but also encourages a close reading of texts with a view to revealing cultural assumptions and meanings that are not readily visible (Johnson, Clarke and Dempster 2005). This perspective informed the generation of the following questions that were used to analyse the documents:

- What purposes is the policy focussed on (i.e., what problem is it seeking to address)?

- What assumptions underpin the policy (e.g., about students, students' decision-making, their social contexts and need for institutional support)?

- What concept of transitions is articulated by the policy?

- What measures does it propose?

- In what ways does the policy aim to promote or provide 'institutional bridges' between school and work? and

- In what ways does it stand to reproduce and/or redress social inequalities?

Each of the policy documents was read independently by two of the authors. Their combined responses were then appraised collectively to consider the internal consistency within each document and identify key common themes across documents. Given the variation in their form and presentation, the analysis subsequently focussed on identifying thematic patterns within and across the documents. The findings of these analyses are discussed in the next section.

\section{Educational purposes and curriculum goals and means}

The analysis of documents, while acknowledging their different forms, purposes and formats, identified patterns in the: (a) range of intents that have some commonalities in terms of broad educational purposes focused on enhancing transitions from school, (b) more specific set of curriculum goals that were identifiable within and across these documents, and (c) range of curriculum means (i.e., initiatives, strategies and processes) for securing both overriding purposes and particular curriculum goals. These are now discussed in turn.

\section{Educational purposes}

A central educational purpose that was rehearsed repeatedly across the set of documents was for all students to secure successful transitions from school either to employment or further education. The emphasis here was on the production of a highly skilled workforce to ensure economic prosperity. Successful transitions were associated with two sub-purposes: (i) the preparation of all students to participate fully in social and economic activities in their post-school life and (ii) through this participation redressing inequalities and disadvantage. The range of forms, purposes and formats were expressed in a variety of central educational purposes. For example, the Australian Capital Territory's (2006) focus on reviewing existing secondary college structures "to fully and effectively meet the 21 st Century educational needs of all young people" (p.15) emphasised the need "to strengthen the continuity of the curriculum for all students" (p.13) despite the challenges faced by the colleges in catering for "those at risk of not pursuing a pathway to a meaningful life" (p.14). In Queensland's (2002) wider proposals for education and training reform, the central purposes were invoked more explicitly in the document's Foreword in a vision statement from the State's Premier and ministers responsible for education and training: 
Our vision for the Smart State is to create a state of prosperity and social justice with a commitment to equality of opportunity. Education and training are at the heart of the Smart State vision and that means providing the very best learning opportunities possible for every young Queenslander regardless of their economic and social circumstances. ... A well-educated and skilled population has become a defining characteristic of a modern society with high living standards. To compete in today's world, young Queenslanders need exciting and flexible pathways from school to work, training or further education. (p.4)

In contrast to the Queensland document, New South Wales' (2006) education and training strategy provided far less detail on the development of policy and communicated a more pithy statement of educational purposes:

We aspire to a future where all 15-19 year olds are well equipped to make meaningful life choices and to become active participants in their communities, in our democracy and increasingly as global citizens. For this to occur, and to secure their economic future, young adults will need to be fully engaged in education, training or skilled employment. We are committed to increasing the retention rates and engagement of 15-19 year olds in education and training. (p.1)

Briefly, the other documents convey similar purposes: the Northern Territory's (2006) vision is that "all students make a successful transition from school to work, training or further education so they can actively participate in the economic and social development of the NT and Australia" (p.2); South Australia's (2006) review of senior schooling, entitled 'Success for All', builds on the State's Strategic Plan which includes targets "designed to generate education, training and work opportunities for young South Australians and, in turn, support the social and economic development of the state" (p.4); Tasmania's (2003) strategy:

"aims to improve young people's participation in education and training beyond compulsory schooling; to enable second chance learning opportunities for people of all ages; to build a skilled workforce with the capacity to support business and industry in a growing economy; and to create communities that value lifelong learning" (p.1).

The overriding purpose identified in Victoria's (2000) review of post-compulsory education and training pathways is "to engage all young people in education and training of good quality, which will provide the individual with a successful outcome" (p.4).

From this rendering of statements of purpose across these documents, productive transitions are presented as those that encourage students to participate actively in social and economic life and, in doing so, seek to remedy social inequalities of the kind that can inhibit students' full participation in economic and social life beyond school. The concept of 'productiveness' implies school students being able to move directly into worthwhile employment and/or vocationally-specific or higher education.

A theme common to all these policies is that economic growth and social inclusion are interdependent policy objectives that can be achieved by expanding 
education and training opportunities for young people. This overall policy position is characteristic of social investment policy regimes based on third way politics that emerged first in the UK and are currently favoured by social democratic governments in several Anglophone countries including Australia (Dobrowolsky and Jenson 2005; Maroy 2009). On one level, social investment has attempted to address social inequalities that increased as a result of market neoliberal policy orientations that dominated throughout the 1980s and 1990s (Fine 1999; Jones Finer 2004). Here, it is important to note that all Australian state education policies reviewed here were developed under Labor goverments (i.e. purportedly social democratic). However, their policies on social investment have also been sensitive to criticisms of reflecting social welfarism. Hence, they have sought to target expenditure on social programs where there is reasonable expectation of a financial return. For this reason, education and training have become central pillars of social investment because of their assumed importance for supporting economic growth and reducing the risk of social exclusion. It is from these purposes that more specific curriculum goals were identifiable.

\section{Curriculum goals}

Aligned with these purposes were a number of curriculum goals. These goals were associated with: (i) improving students' awareness of post-school options and their requirements, (ii) enhancing retention of at risk school students to the senior years through more effective engagement, and (iii) increasing student aspirations for their post-school lives. These goals also emphasised the need to (iv) develop employability skills, (v) maximise students' capacities and (vi) opportunities for learning and (vii) promote students' agency. They are thus personally utilitarian, yet directed at achieving a fit between individuals' purposes and those of the society and community in which they live. As such, the goals reflect educational intents, that are analogous to what Dewey (1916) proposed as the importance of educational provisions to democracy through enhancing participation in socially-derived activities, such as work, schooling, family and civil life. This participation presupposes that individuals have access to information about the purposes to which they should direct their efforts as they seek pathways to post-school life. Furthermore, it assumes that students are empowered to then act as unconstrained, critical consumers to enact decisions based on that information.

The curriculum goals across these documents aimed to assist young people to identify work to which they are best suited and to develop the capacities to realise pathways to this work. In this way, they were principally about maximising the social and economic resources that young people acquire through schooling rather than seeking to improve educational and transition outcomes for disadvantaged or at-risk students. Therefore, the policy focus is directed at increasing retention and engagement and developing young Australians' capacities to secure benefits, for themselves and for the nation. In the South Australian document, it states clearly the concern:

[That] the rate of withdrawal increases markedly between the tenth and twelfth year of schooling, and has done so every year for a decade or more, suggests that systemic factors are operating to draw students away from full-time school education in the middle and senior years. (South Australian Government 2006, 6) 
Furthermore, many of the educational intents emphasise empowering students through making them aware of the world beyond schooling, opening up and increasing their aspirations and positioning them as empowered learners. For example, the Tasmanian strategy (2003) explains a successful "transition" as evidenced by young people who acquire the knowledge, skills and attributes that will enable them:

0 to realise their full potential and

$\circ$ to participate in and contribute to society.

Similarly, the ACT document refers to students' view of adultness: "Adultness" has become strongly associated with notions of independence, freedom, self-reliance and personal choice" (Atelier Learning Solutions 2005, 13). These aspirations are consistent with policy notions of the active and responsible citizen discussed above whose ethical commitments are oriented to participation in productive economic activity.

In contrast, Bauman (2000), no doubt, would hope for far more critically reflexive educational purposes, aimed at assisting students understand and critique the growing emphasis on the individual in the relations between persons and society, in matters of education and work. Yet, perhaps more fundamentally here, there is a need for schooling to attempt to ameliorate for the lack of access to cultural and social capital as Friere (1985) advocated and practiced. Bauman's (2000) and Freire's (1985) perspectives together suggest that a uniform approach to achieving curriculum goals is unlikely to be successful. On the contrary, goals will need to be met in ways that attempt to overcome the limitations for those who cannot access the kinds of cultural, social and economic capital that have been shown to shower advantage on those afforded it. Put baldly, in placing an emphasis on the individual, those who are less well positioned personally, culturally and socially may be further disadvantaged. Hence, it is important to look beyond goals to the kinds of curriculum means suggested in the documents as ways to secure productive transitions.

\section{Curriculum means}

The documents proposed a range of interventions, initiatives and strategies to support productive transitions: categorised here as sets of curriculum means. The means range across: (a) the student-teacher level of engagement, (b) school-based initiatives and (c) engagement with the community beyond school. At the classroom level, proposed curriculum means include: providing student specific support, effective monitoring of students' progress, and finding ways of making the educational experience in schools more inviting and engaging and responsive to students' needs. More specifically, suggestions for greater responsiveness involve contextualising literacy to students' experiences, generating individual plans for progress through senior schooling and finding ways of engaging students productively in the kinds of learning that they need to secure.

Some of these means appear to have the potential to productively support individual student's engagement in schooling. To be most effective, such means require alternative strategies that emphasises understanding, meeting and extending students' readiness for engaging in school-to-employment transitions. For instance, classroom based initiatives that are tailored to students' readiness are more likely to be generative of positive engagement and productive outcomes (Smyth 2006). Such initiatives may contrast with learning approaches that utilise uniform strategies, tasks and outcomes. For example, strategies might aim to assist students become more 
critically reflexive, an essential capacity which all students need to develop to understand the changing character of the societies in which they will live, study and work. However, the bases for developing reflexivity will likely differ across student cohorts.

At an institutional level, one means suggested in the documents is, overall, the provision of a more tailored schooling experience premised upon greater flexibility of educational provisions and experiences. The need for further development of teachers' capacities in providing such experiences is also proposed. The Kirby Report (Victorian Government 2000) recommended for Victorian teachers, professional development in areas of mentoring and case management; program evaluation; and outcomes monitoring. Again, supporting students in ways that acknowledge their diversity of capacities and readiness is made clear; as is the need for flexibility. Yet, flexibility does not always assist in overcoming disadvantage.

The policies also suggest the need to engage with industry and employers and to strengthen engagement with the community, suggestions which extend to securing consensus about support for realising effective transitions. The Northern Territory Government Strategic Plan (2006) is worded to emphasise improving access to school based apprenticeships and traineeships; focusing activity on areas of skill shortage and labour demand; and increasing industry and business involvement in school to work transition. This is consistent with social investment's strategy for targeting programs of government at the level of communities (Rose 1999, 2000). Central to this strategy is the idea of community-based schooling and the constitution of schoolcommunity partnerships (Hay and Kapitzke 2009a; Seddon, Billett, and Clemans 2004) that may work to distribute transition risk for young people across a number of community stakeholders including the business sector (Hay 2009).

Indeed, curriculum means such as these potentially offer bridges that might help to close or avoid gaps between what the experiences of schooling affords young people and what they need to negotiate a successful transition from school. Such institutional bridges might operate in different ways for students: in classroom experiences which accommodate differing needs and capacities, with school procedures that assist and guide individuals to particular outcomes, and between schools and the community beyond schools.

At the system level, the documents clearly identify a need for close articulation between schools and tertiary education. The Kirby Report for example refers to a lack of co-ordination between the education and training systems in Victoria (Victorian Government 2003). This articulation may need to extend to provisions that engage with the community and provide access to a range of perspectives about employment opportunities available, the kinds of capacities required to secure those opportunities, and the means by which those capacities can be developed. Clearly, factors beyond the school advantage some students' capacities to secure productive pathways as much as they present barriers to others. Hence, there is a need to exercise articulations effectively to enhance-particularly for at-risk students - their connectedness to institutional forms of social capital that facilitate desirable transitions. Yet these will come at significant resource cost. Ironically, the cost of providing high levels of support may fall most heavily on the schools that need to address disadvantage most strongly, as it may be available for other schools gratuitously through families' social and cultural capital.

Consequently, these means identify bases by which schools might become more invitational to and address the readiness of all kinds of students. This includes attempting to ameliorate for the diminished access to the kinds of capital that are 
likely to be advantageous for students' transitions. In addition, the need for teachers to guide and support students in aligning their interests and capacities with possible occupational outcomes is seen to be important. In particular, at-risk students stand to be the ones for whom these arrangements are most important. Identifying and implementing the curriculum means required to meet their needs, engage them productively and fully utilise their agency as learners will be challenging. Ultimately, it is these students for whom the transition to post-school is the most perilous and whose prospects for negotiating productive transitions are weakest.

\section{Purposes, goals and curriculum means: individualisation and societal forms}

As foreshadowed, this paper examines the policy context of transitions from senior schooling. The analysis of current Australian senior schooling policies suggests a growing emphasis on the individualisation of educational processes and outcomes related to post-school transitions - an emphasis that aligns with broader societal trends where individualisation is seen as unavoidable in a world that is increasingly uncertain and prone to change. Government policies contribute to these processes by emphasising a need for individuals to fully exercise their personal agency in making decisions about, participating in and securing outcomes through educational and training choices. Yet, despite these universal demands made on young people, the readiness or capacity of many students to engage in contexts that emphasise this agency both inside and outside of the school is far from clear. While all students have access to some forms of cultural, economic and social capital, not all such forms are equally supportive for negotiating post-school transitions. Hence, although schooling cannot compensate for the limits of some students' access to advantageous forms of capital (Teese 2000), it will need to take into account students who are poorly placed to effectively negotiate their transitions. Moreover, some students' capacities will be far more aligned to realising preferred and more highly esteemed destinations than others. Similarly, therefore, educational means may need to be directed towards redressing these differences and their social consequences.

Without curriculum means that specifically aim to redress the lack of access to forms of capital that can support students realising productive transitions, many will potentially be doubly disadvantaged - during the transition process and in engaging in lives after schooling. While it is important not to over-estimate the impact of indeterminate transitions to post-school destinations, it is likely that the consequences for unproductive transitions will be distinct across student cohorts. Those without access to supportive social, economic and cultural capital and the readiness to negotiate transitions effectively are typically those who require these capacities the most. It is the support needs of these students that should be recognised as a policy priority.

\section{Acknowledgements}

The authors acknowledge the support provided by the Australian Research Council Discovery Projects scheme to undertake the research reported here.

The authors also acknowledge the important contribution made by Elizabeth Hirst in the initial stages of the project including early work on this paper.

\section{References}


Atelier Learning Solutions. 2005. Government Secondary Colleges in the Australian Capital Territory: Challenge, opportunity, renewal. Canberra: ACT Department of Education and Training.

Australian Chamber of Commerce and Industry \& Business Council of Australia. 2002. Employability skills for the future. Canberra: Department of Education, Science and Training.

Australian Labor Party. 2007. Skilling Australia for the future. Canberra: ALP.

Ball, S., S. Macrae, and M. Maguire. 1999. Young lives, diverse choices and imagined future in education and training markets. International Journal of Inclusive Education 3, no. 3: 195-224.

Ball, S. 2003. Class strategies and the education market: The middle classes and social advantage. London: RoutledgeFalmer.

Bauman, Z. 2000. The individualized society. Cambridge: Polity Press.

Bauman, Z. 2002. Society under siege. Cambridge: Polity Press.

Beck, U. 1992. Risk society: Towards a new modernity Trans. M. Ritter. London: Sage.

Beck, U. and E. Beck-Gernsheim. 2002. Individualization: Institutionalized individualism and its social and political consequences. London: Sage.

Bedson, L., and D. Perkins. 2006. A positive influence. Equipping parents to support young people's career transitions Evaluation of the PACTS program. Fitzroy, Vic.: Brotherhood of St Laurence.

Billett, S. 2006. Work, subjectivity and learning. In Work, subjectivity and learning, ed. S. Billett, T. Fenwick, and M. Somerville, 1-17. Dordrecht: Springer.

Billett, S., C. McKavanagh, F. Beven, L. Angus, T. Seddon, J. Gough, S. Hayes and I. Robertson. 1999. The CBT decade: Teaching for flexibility and adaptability. Adelaide: National Centre for Vocational Education Research.

Bourdieu, P. 1990. In other words: Essays towards a reflexive sociology. Stanford, CA: Stanford University Press.

Bourdieu, P., and J.C. Passeron. 1977. Reproduction in education, society and culture. London: Sage.

Breen, R., and J.O. Jonsson. (2005). Inequality of opportunity in comparative perspective: Recent research on educational attainment and social mobility. Annual Review of Sociology 31: 223-43.

Connell, R. W. 2003. Working-class families and the new secondary education. Australian Journal of Education 47, no. 3: 235-51.

Dean, M. 1999a. Governmentality: Power and rule in modern society. London: Sage.

Dean, M. 1999b. Risk, calculable and incalculable. In Risk and sociocultural theory: New directions and perspectives, ed. D. Lupton, 131-59. Cambridge: Cambridge University Press.

Department for Children Schools and Families. 2007. Raising expectations: Staying in education and training post-16: From policy to legislation. Nottingham: Department for Children Schools and Families.

Dewey, J. 1916. Democracy and education. New York: The Free Press.

Dobrowolsky, A., and J. Jenson. 2005. Social investment perspectives and practices: A decade in British politics. In Social policy review 17: Analysis and debate in social policy, ed. M. Powell, L. Bauld and K. Clarke, 203-230. Bristol: The Policy Press.

Edwards, R. 2002. Mobilizing lifelong learning: Governmentality in educational practices. Journal of Educational Policy 17, no. 3: 353-65.

Erikson, E. H. 1968. Identity, youth and crisis. New York: Norton. 
Evans, K. 2002. Taking control of their lives? Agency in young adult transitions in England and the New Germany. Journal of Youth Studies 5, no. 3: 245-69.

Field, J. 2000. Governing the ungovernable: Why lifelong learning promises so much yet delivers so little. Educational Management and Administration 28, no. 3: 249-61.

Fine, B. 1999. The development state is dead - Long live social capital. Development and Change 30: 1-19.

Freebody, P. 2003. Qualitative research in education: Interaction and practice. London: Sage Publications.

Freire, P. 1985. The politics of education: Culture, power and liberation. Boston, Mass: Bergin \& Garvey Publishers.

Gonon, P. 2009. 'Efficiency' and 'Vocationalism' as structuring principles of industrial education in the USA. Vocations and Learning: Studies in Vocational and Professional Education 2, no. 2: 75-86.

Hay, S. 2009. Transforming social and educational governance: Trade Training Centres and the transition to social investment politics in Australia. British Journal of Educational Studies 57, no. 3: 285-304.

Hay, S., and C. Kapitzke. 2009a. School industry partnerships: Constituting spaces of global governance. Globalisation, Societies and Education 7, no. 2: 203-16.

Hay, S., and C. Kapitzke. 2009b. 'Smart' state for a knowledge economy: Reconstituting creativity through student subjectivity. British Journal of Sociology of Education 30, no. 2: 151-64.

Heinz, W. R. 2009. Structure and agency in transition research. Journal of Education and Work 22, no. 5: 391-404.

Hodges, D. C. 1998. Participation as dis-identification with/in a community of practice. Mind, Culture and Activity 5, no. 4: 272-90.

Johnson, G., S. Clarke, and N. Dempster. 2005. The discursive (re)construction of parents in school texts. Language and Education 19, no. 5: 380-99.

Jones Finer, C. 2004. Putting a positive gloss on welfare state restructuring: Recent British experience. Melbourne: Brotherhood of St Laurence and the Centre for Public Policy, University of Melbourne.

Kelly, P., and J. Kenway. 2001. Managing youth transitions in the network society. British Journal of Sociology of Education 22, no. 1: 20-33.

Maroy, C. 2009. Introduction to the sub-issue: 'new modes of regulation of education systems'. Compare 39, no. 1: 67-70.

McMillan, J., and G. Marks. 2003. School leavers in Australia: Profiles and pathways. LSAY report 31. Camberwell: ACER.

Miller, P., and N. Rose. 2008. Governing the present. Polity Press.

New South Wales Department of Education and Training. 2006. Our 15 to 19 year olds - Opportunities and choice. An education and training strategy for 15 to 19 year olds in NSW 2006 - 2009. Sydney: Department of Education and Training.

Northern Territory Government. 2006. School to work transition strategic plan 20072009. Darwin: Department of Employment, Education and Training.

O'Malley, P. 2004. Risk, uncertainty and government. London: Glasshouse Press.

OECD. 2009. Education Today: The OECD Perspective. http://www.oecd.org/document/ 57/0,3343,en_2649_33723_42440761_1_1_1_1,00.html.

Peters, M. 2005. The new prudentialism in education: Actuarial rationality and the entrepreneurial self. Educational Theory 22, no. 3: 267-82. 
Pollock, E., P. Chandler, and J. Sweller. 2002. Assimilating complex information. Learning and Instruction 12: 61-86.

Queensland Government. 2002. Education and training reforms for the future: A White Paper. Brisbane: Department of Education and the Arts.

Quicke, J. 1999. A curriculum for life: Schools for a democratic learning society. Buckingham: Open University Press.

Raffe, D. 2008. The concept of transition system. Journal of Education and Work 21, no. 4: 277-96.

Ray, C. 2005. Individualisation and the third age. Discussion paper series 5. Newcastle Upon Tyne: Centre for Rural Economy, University of Newcastle Upon Tyne.

Rose, N. 1996. Governing "advanced" liberal democracies. In Foucault and political reason: Liberalism, neo-liberalism and rationalities of government, ed. A. Barry, T. Osborne and N. Rose, 19-36. London: UCL Press.

Rose, N. 2000. Community, citizenship, and the third way. American Behavioral Scientist 43, no. 9: 1395-1411.

Rose, N., and P. Miller. 1992. Political power beyond the state: Problematics of government. British Journal of Sociology 43, no. 2: 173-205.

Seddon, T., S. Billett, and A. Clemans. 2004. Politics of social partnerships: a framework for theorizing. Journal of Education Policy 19, no. 2: 123-42.

Shanahan, M. J., and Hood, K. E. 2000. Adolescents in changing social structures: Bounded Agency in life course perspective. In Negotiating adolescence in times of social change, eds. L. J. Crockett and R. K. Silbereisen. 123-134. Cambridge: Cambridge University Press.

Sigelman, C. K. 1999. Life-span human development. Vol. 3. Pacific Grove: Brooks/Cole Publishing Company.

Simmons, R. 2009. Entry to employment: discourses of inclusion and employability in workbased learning for young people Journal of Education and Work, 22, no. 2: 137-151.

Simmons, R. 2008. Raising the age of compulsory education in England: A NEET solution? British Journal of Educational Studies 56, no. 4: 420-439.

Smyth, J. 2006. 'When students have power': Student engagement, student voice, and the possibilities of school reform around 'dropping out' of school. International Journal of Leadership in Education 9, no. 4: 285-98

South Australian Government. 2006. Success for all: SACE review. Adelaide: Department of Education and Children's Services.

Stokes, H., and J. Wyn. 2007. Constructing identities and making careers: Young people's perspectives on work and learning. International Journal of Lifelong Education 26, no. 5: 495-511.

Tasmanian Government. 2003. Tasmania: A state of learning. Hobart: Department of Education.

Taylor, S., F. Rizvi, B. Lingard, and M. Henry. 1997. Educational policy and the politics of change. London: Routledge.

te Reile, K. 2004. Youth transition in Australia: Challenging assumptions of linearity and choice. Journal of Youth Studies 7, no. 3: 243-257.

Teese, R. 2000. Academic success and social power: Examinations and inequality. Carlton: Melbourne University Press.

Vanoverberghe, J., D. Verhaest, E. Verhofstadt, and E. Omey. 2008. The transition from school to work in Flanders: A duration analysis. Journal of Education and Work 21, no. 4: 317-331. 
Victorian Government. 2000. Ministerial review of post-compulsory education and training pathways in Victoria. Final report. Melbourne: Department of Education, Employment and Training.

Walther, A., M. du Bois-Reymond, and A. Biggart, eds. 2006. Participation in transition: Motivation of young adults in Europe for learning and working. Frankfurt: Peter Lang.

Western Australian Government. 2005. Vocational education and training for school students in Western Australia. Ministerial Policy Statement. Perth: Department of Education and Training.

Wyn, J., and Dwyer, P. 1999. New directions in research on youth in transition. Journal of Youth Studies 2, no. 1: 5-21. 